\title{
KAJIAN BUKU
}

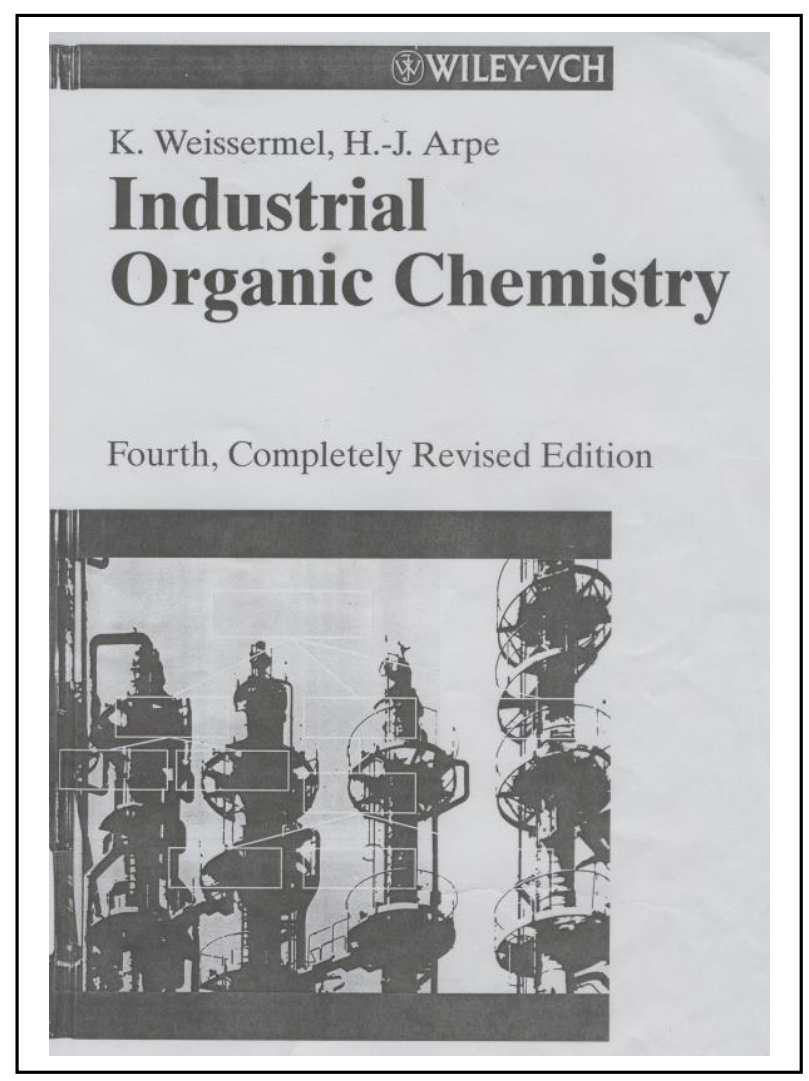

Judul Buku
Penulis
Tahun terbit
Penerbit
Halaman
Harga

: Industrial Organic Chemistry

Fourt, Completely Revised Edition

: K. Weissermeland dan Hans-Jurgen

Arpe

: 2003

Wiley-VCH GmbH \& Co. KgaA, Weinheim

: $\quad 491+$ XIX

Rp. $1.534 .500,00$

\section{Kimia Organik Industri}

\section{F. Sinung Pranata}

Fakultas Biologi, Universitas Atma Jaya Yogyakarta, Jl. Babarsari 44,

Yogyakarta-55281

e-mail:sinung@mail.uajy.ac.id

Perkembangan yang pesat di bidang industri kimia telah membuat Klaus Weissermel dan Hans-Jurgen Arpe membuat edisi baru dari buku Kimia Organik Industri. Buku ini merupakan revisi dari edisi pertama dan telah diterjemahkan ke dalam delapan bahasa. Pada tahun 1976, Weissermel dan Arpe menerbitkan buku ini pertama kali di Jerman. Buku tersebut mendapat sambutan positif dari para koleganya. Tidak lebih setahun kemudian edisi kedua telah diterbitkan dengan dilengkapi data terbaru dari berbagai industri kimia di dunia.
Bab pertama buku ini lebih menyorot tentang ketersediaan gas alam dan minyal sebagai bahan baku industri kimia. Berbaga pendapat diberikan untuk menjag kelangsungan suplai bahan baku tersebut $\mathrm{d}$ satu sisi, sedangkan di sisi lain diberika tanggapan berupa cara untuk teta meningkatkan produk industri kimia. Alternati sumber-sumber energi masa depan masih teta perlu dicari, misalnya yang berasal dar nuklear, matahari, dan geotermal. Selain it penulis juga memberikan cara untu. 
menyiasati krisis bahan baku saat ini dengan memperkenalkan teknologi thermal cracking.

Dalam buku ini Weissermel dan Arpe mengupas berbagai macam produk yang dihasilkan dari industri kimia. Bab tentang olefin sangat menarik untuk dibaca, karena olefin dapat digunakan sebagai pengganti asetilen yang telah lebih dulu menjadi primadona industri kimia organik. Demikian pula bab tentang produk hasil oksidasi etilen, yaitu oksiran yang ternyata mampu menyaingi karakter low and high density polyethylene walaupun faktor harga masih menjadi kendala produksi.

Secara lengkap penulis juga membahas produk-produk kimia dari alkohol. Mereka membahas proses pembuatan etil klorida dengan mengintegrasikan proses klorinasi. Bahan-bahan dengan reaktivitas tinggi, seperti komponen vinil mendapat sorotan dalam buku ini. Perkembangan produk vinil klorida dan asetat semakin maju dengan ditemukannya proses termolisis dari etilen. Proses ini jauh lebih efisien dari segi biaya dan proses dibandingkan proses pembuatan vinil klorida dari asetilen. Bab tentang senyawa aromatik dibahas mulai dari proses isolasi, produksi, dan konversinya. Senyawa aromatik telah digunakan secara luas untuk pembuatan plastik, serat, dan karet sintetik. Proses-proses konversi, seperti hidrodealkilasi toluen mampu menghasilkan kemurnian produk lebih dari $90 \%$.

Buku ini disusun menjadi 14 bab yang dapat dibagi menjadi 3 bagian besar. Bagian pertama mengenai Faktor yang Berpengaruh terhadap Suplai Energi dan Bahan Mentah (Bab 1), bagian kedua tentang Produk-produk Dasar yang dapat Diproduksi secara Industri, dan bagian ketiga mengenai Proses Pembuatan beberapa Produk seperti dari Olefin, Asetilen, Etilen, Alkohol (Bab 3 sampai 14).

Buku ini memang layak dibaca baik oleh yang terkait langsung maupun tidak langsung dengan industri kimia organik. Buku ini memang menggabungkan informasi dari industri, universitas, dan rangkuman hasil diskusi dari para ahli. Penyajian informasi dibuat cukup mendetail, yaitu dengan menampilkan teks utama, sinopsis dari teks utama yang ditempatkan pada kolom tersendiri, dan diagram alir yang menggambarkan hubungan masing-masing produk pada setiap bab. Buku ini hadir dengan harapan dapat memenuhi keinginan pembaca dari berbagai lapisan, mulai dari mahasiswa, dosen, ahli kimia, bahkan marketing dan pengacara serta ekonom sekalipun yang berkecimpung di industri kimia. 